\title{
SCHOOL-COMMUNITY RELATIONSHIP AND SCHOOL SYSTEM EFFECTIVENESS IN SECONDARY SCHOOLS IN CROSS RIVER STATE
}

\author{
Owan, Valentine J. ${ }^{1} \quad$ Department of Educational Administration and Planning, University of \\ Calabar, Calabar, Nigeria \\ Email:owanvalentine@gmail.com
}

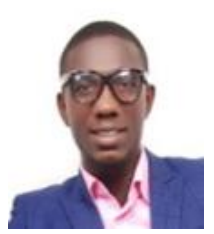

Article History

Received: 10 January 2019 Revised: 19 February 2019 Accepted: 26 March 2019 Published: 8 May 2019

\section{Keywords}

School-community School-community relationship System effectiveness School system effectiveness System effectiveness School system.

\begin{abstract}
This study assessed school-community relationship and school system effectiveness in secondary schools in Cross River State. Four null hypotheses were formulated accordingly as guide to the study. The study adopted descriptive survey research design. A total of 1,480 academic staff which comprised 271 principals, and 396 vice principals selected through census technique, and 813 teachers selected using simple random sampling technique, were used to elicit data for the study. "School-Community Relationship and Secondary School System Effectiveness Questionnaire (SCRSSSEQ)" was used as instrument for data collection. Collected data were analyzed using descriptive statistics, while the null hypotheses were all tested at .05 level of significance using Pearson Product Moment Correlation with the aid of SPSS version 21. Findings from the study revealed that: parent-teachers' relationship, schoolcommunity use of resources, school-community communication and school-community collaboration are significantly related to secondary school system effectiveness respectively, in Calabar Municipal Area of Cross River State. It was concluded that generally that school community relationship has significant relationship with school system effectiveness respectively. Based on the findings of this study, it was recommended among others that; principals should setup active parents' teachers' associations in their schools with leaders of the association comprising of community members and staff of the school. This will serve as a link that binds the school to the community and will create a platform for discussing and settling disputes.
\end{abstract}

Contribution/Originality: This study is one of very few studies which have investigated and addressed the concerns underlying poor school system effectiveness in Cross River State. The study also used a unique approach to explore some variables of school community relationship which are rare in previous studies.

\section{INTRODUCTION}

It is obvious that the school is a system with related sub-systems. Therefore, it is imperative that all the subunits within the school, work harmoniously to the realization of stated objectives of the school. The ability of the school manager in unifying available human and material resources at his disposal, can be used to describe such a manager as either effective or ineffective. On the other hand, the overall activities that takes place in the school, can be used as parameters for assessing whether a school system is effective or not. School system effectiveness refers to the extent to which every unit within a school, carry out their routine functions that can promote or hinder the attainment of set objectives.

An effective secondary school system is one that has motivated teachers, positive students' academic performance, good relationship with the community, good leadership, effective school climate, and one that attain 
set goals. An effective school system is characterized by strong administrative leadership, high expectations, an orderly atmosphere, basic skills acquisition (the schools' primary purpose), capacity to divert school energy and resources to advance the school's basic purpose, and frequent monitoring of pupil progress. Similarly, Scheerens (2016) added that, achievement orientation, high expectations, teacher expectations, educational leadership, consensus and cohesion among staff, curriculum quality, opportunity to learn, school climate, evaluative potential, classroom climate, effective learning time (classroom management), structured instruction, feedback/reinforcement and parental involvement, are all indicators of an effective school system. The following indices as correlates of school effectiveness: instructional leadership, clear and focused mission, safe and orderly environment, climate of high expectations, frequent monitoring of student progress, positive home-school relations, opportunity to learn and student time on task.

Given the indices of effective school system highlighted above, it is quite glaring and unfortunate that many secondary schools in Cross River State, do not appear to have met such criteria. This is because of the poor performance of teachers, school principals, and students. The attitude of most teachers in the area are questionable, and have been observed many times, to have contradicted the professional ethics of teaching. Most secondary school principals especially those in public schools have also been observed to be naive and less concerned about the activities of the school. This is seen when such school routines clash with their own other personal interest. With the high rate of examination malpractice amongst students and teachers it appears that both the teachers and students in most secondary schools, are incompetent, unprofessional, lazy and corrupt.

An attempt to redress these issues, has made the researchers to consider school-community relationship as an area that may have contributed to this poor trend of school system ineffectiveness. According to Bala (2013) the success or failure of secondary schools depends to a large extent, on the level of relationship the schools maintain with their neighboring communities. School community relationship is a two-way symbiotic arrangement through which the school and the community co-operate with each other for the realization of goals of the community and vice versa. It is the degree of understanding and goodwill, which exists between the school and the community (Okorie et al., 2009). This paper examined school-community relationship from the perspective of parent-teachers relationship, school-community use of resources, school-community communication and school-community collaboration.

Parent-teacher relationship refers to the connection that exist between the teachers of students and the parents of students. The students are the bond and the link a teacher has to parents. when parents are enabled to become effective partners in their child's education, performance in schools where children are failing improves dramatically, and that schools that work well with families, where parents are involved: outperform identical programs without parent and family involvement; have improved teachers' morale and higher rating of teachers by parents; and have more support from families and a batter reputation in the community.

School community use of resources is the symbiotic exchange of school or community resources between the school and the community. Such resources include: land, buildings, school halls, town halls, playgrounds, chairs and so on. According to Bala (2013) schools and communities can partner with each other in the use of different facilities. Both schools and communities can benefit from use of each other's facilities such as clinics, transport facilitates, sources of water, restaurants, etc. These kinds of partnerships are forged between schools and organizations. The partnerships are often made between local business and schools. The aims of these partnerships are focused on exposing students to careers and work skills, with the sponsoring organization benefiting from free or cheap labor.

Schools and communities share and disseminate information through communication with each other. Communication involves sharing and transmitting message ideas or attitudes among administrators, teachers, students, parents and other interested constituents. Information sharing, and dissemination is a give-and-take 
process that requires perfect partnership between schools and communities for a better result. It is the flow of information between the leaders or teachers of the school, and the leaders or parents of the community (Bala, 2013).

School community collaboration can be defined as a situation where both the school and the community join efforts together to provide certain essential services for the school or the community, depending on the need. In this regard, Bala (2013) noted that schools can help families gain access to support services offered by other agencies such as health care, cultural events, tutoring service, and after school child care programs. They also can help families and community groups provide services to the community, such as recycling programs and food pantries.

Several studies have been conducted which tried to uncover the association of school community relationship and other variables of school system effectiveness. Anthony et al. (2017) investigated the influence of schoolcommunity relationship on the management of secondary schools in Southern Senatorial District of Taraba State. Four research questions and four hypotheses guided the study. The descriptive survey design was adopted for the study. Mean scores and standard deviation were used to answer the research questions, while single factor analysis of variance (ANOVA) was used to test the hypotheses at 0.05 level of significance. The study found out that Parents' Teachers' Associations, Old Students' Associations, school committees and school board of governors have significant influence on the management of secondary schools. The researchers recommended that Parents and teachers should not allow the management of their schools to the hands of the school administrators alone hence their contribution is vital and necessary for the development of the schools.

Bakwai (2013) assessed school-community relationship among secondary schools in Zamfara State. The population of the study consisted of all the principals, vice principals, teachers and PTA officials of the 89 Senior Secondary Schools in Zamfara State. Among the major findings of the study is that school community relationship is very important in determining the rate at which activities in Secondary Schools in Zamfara State were carried out. The study revealed that both the communities and the schools engaged in maximum cooperation and utilization of facilities such as school field, school halls, town hall, festivals etc. It was recommended that schools should necessarily understand the opinion of communities regarding both broad educational issues and day to day operation of the schools themselves. It was also recommended that vigorous campaign should be launched at both the State and Local government level to sensitize citizens on the need for their participation in the education of their children.

Uzoechina (2016) investigated the status and barriers to good school-community relationship in secondary schools in Anambra State. Guided by two research questions, the sample was 1,818 respondents (80 principals, 1678 teachers and 60 community rulers) selected through stratified random sampling. Data, collected through a 21-item researcher developed questionnaire, was analyzed using mean scores. The findings revealed that the schoolcommunity relationships existing in secondary schools in Anambra state was poor. Fraud, principals'/teachers' attitudes, community apathy and illiteracy among community members were similarly identified by principals, teachers and community rulers as the barriers to good school-community relationship. It was recommended among other things that Principals and teachers should encourage good rapport between them and the community leaders. They should make more efforts to see community involvement in school affairs not as threat but as one way of enhancing its quality.

In another study, Ajayi et al. (2009) examined the relationship between parents' involvement in school administration and effectiveness of secondary schools in Nigeria. The population consisted of all the teachers, principals and parents of the students in public secondary schools in South-West Nigeria. The Data were analyzed using frequency counts, percentage scores and Pearson product moment correlation. The only hypothesis formulated in the study was tested at 0.05 level of significance. The study revealed that parents were much involved in the administration of secondary schools in Nigeria. The study also revealed that secondary schools in the area covered were moderately effective. However, the study showed that there was no significant relationship between parents' involvement in school administration and effectiveness in schools. It was recommended that the school 
administrators should sustain the high level of parents' involvement in school administration in order to maintain cordial relationship between the parents and the school authorities. Since parents' involvement in school administration was not significantly related to the effectiveness of the schools, the government and other stakeholders should make the teaching learning environment of the schools more conducive in order to improve their effectiveness.

In a similar study, Ugwuanyi (2003) examined strategies for involving the community in secondary school administration in Nsukka education zone of Enugu State. The research design used was descriptive survey. The sample comprised the entire population of the study which is seventy- seven principals in the area. Data were analyzed using mean and t-test statistics. The findings of the study revealed that principals have a positive perception towards community participation in school administration with a grand mean of 3.62 which was above the criterion mean of 2.50. It showed that communities are actively involved in secondary school administration with a grand mean of 3.76 above the mean of 2.50. It also revealed that strategies such as employing nonprofessional staff from the community, decentralization of administrative power to embrace communities, sharing of information and decision making with communities, and involving the P. T. A. in school disciplinary committee can be used to involve communities in active administration of secondary schools.

The foregoing has presented a case for why the need for school-community relationship shouldn't be overemphasized. The school cannot exist in isolation but in cooperation with the community or society in which it finds itself. The success or failure of the school system, (principals, teachers and students) depends to a large extent, on the general educational environment of the communities and their value system. It was on this note, that this study was conducted to investigate "school-community relationship and school system effectiveness in secondary schools of Cross River State, Nigeria.

\subsection{Statement of the Problem}

The state of secondary school effectiveness in Cross River State is dangling. It is gradually becoming a norm where all the parties involved in the training of the child such as teachers, principals and non-academic staff, and the children themselves are performing below expected standards. Many schools in the area have been observed to be engaging in serious conflicts with the communities in which such schools reside. These conflicts have further degenerated into poor relationship between the school and the host community. For instance, there was a situation where a parent mobilized family members to intrude the school and beat up a teacher mercilessly, just because the teacher disciplined her child. In trying to react to this, the school principal was out rightly shunned and threatened to keep quiet. Issues like this and even worst cases are occurring that limits the rate at which the school relates with the community. This has also gone further to impede on the way the school and the community operate.

Following government efforts in recent times to improve school system effectiveness by improving teachers' work conditions, providing more facilities, building new schools, recruiting new teachers, and in terms of improved supervision; one expects the secondary schools in Cross River State to be more effective in terms of improved teachers' and students' performance, leadership attitudes of secondary school principals, and the attainment of school goals. It is this deviation from normality that made the researcher to wonder whether school-community relationship has any link to secondary school system effectiveness in Cross River State.

\subsection{Purpose of the Study}

The main purpose of this study was to investigate school-community relationship and school system effectiveness in secondary schools of Cross River State. Specifically, this study sought to examine the relationship between:

i. parent-teachers relationship and school system effectiveness;

ii. school-community use of resources and school system effectiveness; 
iii. school-community communication and school system effectiveness;

iv. school-community collaboration and school system effectiveness.

\subsection{Statement of Hypotheses}

The null hypotheses below, were formulated to guide this study.

i. Parent-teachers relationship is not significantly related to school system effectiveness.

ii. School-community use of resources is not significantly related to school system effectiveness.

iii. School-community communication is not significantly related to school system effectiveness.

iv. School-community collaboration is not significantly related to school system effectiveness

\section{MATERIALS AND METHODS}

The research design adopted for this study was descriptive survey design. Descriptive survey design involves the collection of data to accurately and objectively describe existing phenomena. Studies use this approach to obtain a picture of the present conditions of phenomena. The population of this study include all the academic staff (Principal, vice principal and teachers) of all the 271 public secondary schools in Cross River State. Census technique was employed in selecting the entire population of 271 principals, and 396 vice principals. Simple random sampling technique was employed in selecting three teachers from each secondary school resulting in a sample of 813 teachers selected across the entire secondary school in the area of study. Thus, the number of participants studied were 1,480 .

The instrument used for data collection was a questionnaire titled: "School-Community Relationship and Secondary School System Effectiveness Questionnaire (SCRSSSEQ)". The instrument was designed by the researcher and was divided into two (2) sections. Section A was designed to collect the respondent's personal data, while section B was organized into clusters containing six items each. The questionnaire was made up of 30 items, arranged on a four points Likert-scale. The researcher with the help of three research assistants, administered the questionnaires respectively to all the schools. After the filling process, the completed questionnaires were retrieved from the subjects for analysis.

The data obtained were coded accordingly using person-by-item matrix in Microsoft Excel 2016. Each response was converted to its assigned numeric value. The collected data were analyzed using descriptive statistics; while the null hypotheses were all tested at .05 level of significance using Pearson Product Moment Correlation analysis. SPSS version 21 was used in enhancing the efficiency of the process.

\section{RESULTS AND DISCUSSION}

The results of this study were presented in line with the formulated hypotheses of the study. Interpretation as well as the discussion of the results were integrated accordingly.

\subsection{Hypothesis One}

Parent-teachers' relationship is not significantly related to secondary school system effectiveness. The result of the analysis of data using Pearson Product Moment correlation statistics is presented on Table 1.

Table-1. Summary of Correlation analysis of the relationship between parent-teachers' relationship and school system effectiveness $(\mathrm{n}=1,480)$.

\begin{tabular}{l|c|c|c|c}
\hline Variables & Mean & SD & r-cal. & p-value \\
\hline parent-teachers' relationship & 15.38 & 5.255 & \\
\hline School system effectiveness & & & $.589 * *$ & \\
\hline ** Significant at 01 level; $\mathrm{d} f=1478.000$ & 5.459 & \\
\hline
\end{tabular}


The results presented in Table 1, revealed that the p-value .000 is less than .05 level of significance at 1478 degrees of freedom. With this result, the null hypothesis was rejected implying that; parent-teachers' relationship is significantly related to secondary school system effectiveness in Cross River State. There was a moderate positive relationship $\left(\mathrm{r}=.589^{* *}\right)$ between the two variables. The finding of this study agrees with that of Anthony et al. (2017) which discovered that Parents' Teachers' Associations, Old Students' Associations, school committees and school board of governors have significant influence on the management of secondary schools. This finding good on to imply that when PTA is setup in schools, it gives the community an opportunity to contribute meaningfully to the growth of the school through various projects, recruitment of teachers, and provision of facilities. Thus, where such parents' teachers' association is missing or inactive, the school may be deprived of such benefits.

\subsection{Hypotheses Two}

School-community use of resources is not significantly related to secondary school system effectiveness. The result of the analysis of data using Pearson Product Moment correlation statistics is presented on Table 2.

Table-2. Summary of Correlation analysis of the relationship between School-community use of resources and school system effectiveness $(\mathrm{n}=$ $1,480)$

\begin{tabular}{|c|c|c|c|c|}
\hline Variables & Mean & SD & r-cal. & p-value \\
\hline School-community use of resources & 15.13 & 5.417 & & \\
\hline & & & $.602^{* *}$ & .000 \\
\hline School system effectiveness & 15.09 & 5.459 & & \\
\hline
\end{tabular}

The results presented in Table 2 , revealed that the p-value of .000 is less than .05 level of significance at 1478 degrees of freedom. As a result, the null hypothesis was rejected which implies that; school-community use of resources is significantly related to secondary school system effectiveness in Cross River State. In addition, there was a moderate positive relationship $\left(\mathrm{r}=.602^{* *}\right)$ between school-community use of resources and secondary school system effectiveness. Thus, the implication of this finding is that the more school and community members exchange the use of resources, it creates mutual understanding which is very important in enhancing the school effectiveness and vice versa.

This finding corroborates (Bakwai, 2013) who assessed school-community relationship among secondary schools in Zamfara State and found that school community relationship is very important in determining the rate at which activities in Secondary Schools in Zamfara State were carried out. This agrees with the finding of the present study. The study also revealed that both the communities and the schools engaged in maximum cooperation and utilization of facilities such as school field, school halls, town hall, festivals etc. This further strengthens the earlier speculation that school community relationship is a two-way affair, which underscores the need for active contribution by both parties.

\subsection{Hypotheses Three}

School-community communication is not significantly related to secondary school system effectiveness. The result of the analysis of data using Pearson Product Moment correlation statistics is presented on Table 3.

Table-3. Summary of Correlation analysis of the relationship between school-community communication and school system effectiveness $(\mathrm{n}=$ 1,480).

\begin{tabular}{|c|c|c|c|c|}
\hline Variables & Mean & SD & r-cal. & p-value \\
\hline School-community communication & 14.99 & 5.469 & & \\
\hline & & & $.567^{* *}$ & .000 \\
\hline School system effectiveness & 15.09 & 5.459 & & \\
\hline
\end{tabular}


The results presented in Table 3, shows that the p-value of .000 is less than .05 level of significance at 1478 degrees of freedom. Consequently, the null hypothesis was rejected indicating that; school-community communication is significantly related to secondary school system effectiveness in Cross River State. The results also revealed a moderate positive relationship $\left(\mathrm{r}=.567^{* *}\right)$ between school-community communication and secondary school system effectiveness. This finding implies that a when the school and the community communicate effectively, it creates room for both parties to settle disputes, discuss plans, and address major issues affecting either party.

In line with this, Uzoechina (2016) revealed from a study that the school-community relationships existing in secondary schools in Anambra state was poor. Fraud, principals'/teachers' attitudes, community apathy and illiteracy among community members were similarly identified by principals, teachers and community rulers as the barriers to good school-community relationship. It was recommended in the study among other things that principals and teachers should encourage good rapport between them and the community leaders. They should make more efforts to see community involvement in school affairs not as threat but as one way of enhancing its quality. The recommendations made as a result of the findings of Uzoechina supports the findings of this study.

\subsection{Hypotheses Four}

School-community collaboration is not significantly related to secondary school system effectiveness. The result of the analysis of data using Pearson Product Moment correlation statistics is presented on Table 4.

Table-4. Summary of Correlation analysis of the relationship between school-community collaboration and school system effectiveness $(\mathrm{n}=1$, $480)$.

\begin{tabular}{|c|c|c|c|c|}
\hline Variables & Mean & SD & r-cal. & p-value \\
\hline School-community collaboration & 14.95 & 5.476 & & \\
\hline & & & $.594 * *$ & .000 \\
\hline School system effectiveness & 15.09 & 5.459 & & \\
\hline
\end{tabular}

The results presented in Table 4, shows clearly that the p-value of .000 is less than .05 level of significance at 1478 degrees of freedom. Thus, the null hypothesis is rejected indicating that; school-community collaboration is significantly related to secondary school system effectiveness in Cross River State. The r value of .594** indicates a moderate positive relationship between school-community collaboration and secondary school system effectiveness.

This finding disagrees with the findings of Ajayi et al. (2009) which revealed there was no significant relationship between parents' involvement in school administration and effectiveness in schools. It was recommended that; since parents' involvement in school administration was not significantly related to the effectiveness of the schools, the government and other stakeholders should make the teaching learning environment of the schools more conducive in order to improve their effectiveness.

The differences in the result of this study and that of Ajayi et al. (2009) may have been due to locational differences, and perhaps the nature of the respondents. While the focus of their study was on parents, this study focused on the community in general. Although parents are components of the components, not every community member is a parent. Thus, these few variations including variations from the instruments used for data collection, may have led to the variation in the findings. However, the finding of this study corroborates the findings of Ugwuanyi (2003) which revealed that; communities are actively involved in secondary school administration with a grand mean of 3.76 above the mean of 2.50. It was also revealed that strategies such as employing nonprofessional staff from the community, decentralization of administrative power to embrace communities, sharing of information and decision making with communities, and involving the P. T. A. in school disciplinary committee can be used to involve communities in active administration of secondary schools. 
Looking at the indices of the school and community collaboration, it is expected that a school with facilities and adequate teachers should be effectively driven. Therefore, if the communities have been active in providing such services, then it can be added that, school's ought to be effective. Where this is not achieved with these measures in place, indicates that the problem lies elsewhere.

\section{CONCLUSION}

It was concluded that generally that school community relationship has a significant relationship with school system effectiveness in Cross River State. Improved school community relationship in terms of parents' teachers' relationship, using each other's resources, communication, and collaboration will improve the quality of secondary schools in terms of effectiveness. When school leaders and community leaders and/or members maintain mutual understanding, both the community and the school will benefit because school-community relationship is a two-way thing; and thus, is not beneficial to only one party.

\section{RECOMMENDATIONS}

Based on the findings of this study, it was recommended that:

i. Principals should setup active parents' teachers' associations in their schools with leaders of the association comprising of community members and staff of the school. This will serve as a link that binds the school to the community and will create a platform for discussing and settling disputes.

ii. The school and the community should allow their resources such as field, school halls, town halls and so on, to be used freely. This will strengthen the relationship and give room for active participation of the community in the schools' business.

iii. The community and school leaders should make sure that there is no communication gap between the school and the community. Where conflict arises, the school and the community leaders should use communication to resolve rather than become aliens to one another.

iv. The school should support the community during certain projects, while the community should also support the school by supporting the schools' project. This is an effective way to collaborate and join forces towards effectiveness in both ends.

Funding: This study received no specific financial support.

Competing Interests: The author declares that there are no conflicts of interests regarding the publication of this paper.

\section{REFERENCES}

Ajayi, I., T.E. Haastrup and B. Arogundade, 2009. Parents involvement in school administration as a correlate of effectiveness of secondary schools in Nigeria. International Journal of Educational Administration and Policy Studies, 1(3): 41-46.

Anthony, M., A. Yaro and I. Pev, 2017. Influence of school-community relationship on the management of secondary schools in Southern Senatorial District of Taraba State, Nigeria. International Journal of Education, Humanities and Multidisciplinary Research, 9(2): 100-114.

Bakwai, B., 2013. Assessment of school community relationship in secondary schools in Zamfara State. M.Ed. Thesis Submitted to the Department of Educational Foundations, Usmanu Danfodiyo University, Sokoto, Nigeria.

Bala, B., 2013. Assessment of school community relationship in secondary schools in Zamfara State. M.Ed Dissertation Submitted to the Department of Educational Foundations, Sokoto. Usmanu Danfodiyo University.

Okorie, N., O. Ememe and R. Egu, 2009. School-community relations in the development of secondary schools: A focus on Aba Educational Zone. African Journal of Education and Development Studies 6(1): 22-38.

Scheerens, J., 2016. Educational effectiveness and ineffectiveness. New York: Springer Publishers. 
Ugwuanyi, S.A., 2003. Strategies for involving the community in secondary school administration in Nsukka Education Zone of Enugu State. Unpublished MED Thesis. UNN.

Uzoechina, G.O., 2016. Analysis of school- community relationship in secondary schools in Anambra State, Nigeria. Division of General Studies, Anambra State University, Uli. Available from: https://www.academia.edu/16200206/Analysis_of_school_community_relationship_in_secondary_schools_in_Anamb $\underline{\text { ra_State }}$

Views and opinions expressed in this article are the views and opinions of the author(s), World Journal of Vocational Education and Training shall not be responsible or answerable for any loss, damage or liability etc. caused in relation to/arising out of the use of the content. 